\title{
ANALISIS STATUS KEBERLANJUTAN PERKEBUNAN KELAPA SAWIT RAKYAT PROVINSI JAMBI
}

\author{
Ida Kurnia Saragih ${ }^{1}$, Dwi Rachmina ${ }^{2}$, dan Bayu Krisnamurthi ${ }^{3}$ \\ 1)Program Magister Sains Agribisnis, Sekolah Pascasarjana, Institut Pertanian Bogor \\ 2,3)Departemen Agribisnis, Fakultas Ekonomi dan Manajemen, Institut Pertanian Bogor \\ Jl. Kamper Kampus IPB Dramaga Bogor, Indonesia \\ e-mail: 1)idasaragih35@gmail.com
}

(Diterima 12 Juli 2019/Disetujui 10 September 2019)

\begin{abstract}
Oil palm plantations are strategic commodities in the national economy and public welfare. Smallholder oil palm plantations as part of the palm oil commodity supply chain currently face business sustainability issues. This study aims to analyze the sustainability of community oil palm plantations based on index assessment using the Rap-Palmoil method through the Multidimensional Scaling (MDS) method. Multidimensional analysis of MDS in terms of economic, social, environmental, institutional, and technological dimensions as aspects examined in this study. This research was conducted in two regencies of oil palm plantations in a broad area of land in Jambi Province, namely Muaro Jambi Regency and Merangin Regency. The data used are primary and secondary data, primary data are obtained from interviews with farmers while secondary data are obtained from the Central Statistics Agency, Plantation Service, and literature that supports this research. Respondents in this study were 99 farmers selected purposively. The results of the multidimensional sustainability analysis of the Jambi Province oil palm plantation sustainability index were 57,79 included in the quite sustainable category. While the results of the sustainability index analysis for the five dimensions are 54,11 (economy), 66,83 (social), 58,64 (environmental), 46,40 (institutional), 59,02 (technology). All dimensions are overall included in the "moderately sustainable" category except the institutional dimension in the "less sustainable" category. The sustainability of oil palm plantations in each dimension has a different sustainability index so that different policies are needed to evaluate the sustainability of community oil palm plantations in Jambi Province.
\end{abstract}

Keywords: institutional dimension, multi dimensional scaling (MDS), sensitive attribute

\begin{abstract}
ABSTRAK
Perkebunan kelapa sawit merupakan komoditi strategis pada perekonomian nasional dan kesejahteraan masyarakat. Perkebunan kelapa sawit rakyat sebagai bagian dari rantai pasok komoditi kelapa sawit saat ini menghadapi permasalahan keberlanjutan usaha. Penelitian ini bertujuan untuk menganalisis keberlanjutan perkebunan kelapa sawit rakyat berdasarkan penilaian indeks dengan menggunakan metode Rap-Palmoil melalui metode Multidimensional Scalling (MDS). Analisis MDS secara multidimensi secara dimensi ekonomi, sosial, lingkungan, kelembagaan, dan teknologi sebagai aspek yang dikaji pada penelitian ini. Penelitian ini dilakukan di dua kabupaten sentra perkebunan kelapa sawit secara luas lahan di Provinsi Jambi yaitu Kabupaten Muaro Jambi dan Kabupten Merangin. Data yang digunakan adalah data primer dan sekunder, data primer diperoleh dari hasil wawancara kepada petani sementara data sekunder diperoleh dari badan pusat statistik, dinas perkebunan, dan literatur yang mendukung penelitian ini. Responden pada penelitian ini merupakan petani yang dipilih secara purposive berjumlah 99 petani. Hasil analisis kerberlanjutan multidimensi indeks keberlanjutan perkebunan kelapa sawit Provinsi Jambi sebesar 57,79 termasuk dalam kategori cukup berkelanjutan. Sedangkan hasil analisis indeks keberlanjutan untuk ke-lima dimensi masingmasing adalah 54,11 (ekonomi), 66,83 (sosial), 58,64 (lingkungan), 46,40 (kelembagaan), 59,02 (teknologi). Keseluruhan masing-masing dimensi termasuk dalam kategori "cukup berkelanjutan" kecuali dimensi kelembagaan dengan kategori "kurang berkelanjutan". Keberlanjutan perkebunan kelapa sawit pada masing-masing dimensi memiliki indeks keberlanjutan yang berbeda-beda sehingga diperlukan kebijakan yang berbeda untuk mengevaluasi keberlanjutan perkebunan kelapa sawit rakyat di Provinsi Jambi.
\end{abstract}

Kata kunci: atribut sensitif, dimensi kelembagaan, multi dimensional scaling (MDS) 


\section{PENDAHULUAN}

Pembangunan berkelanjutan merupakan suatu konsep pembangunan untuk memenuhi kebutuhan manusia saat ini tanpa mengganggu kemampuan generasi berikutnya dalam memenuhi kebutuhan hidup generasi yang akan datang. Perkembangan aktivitas binsis mengalami pergeseran paradigma dimana motif awalnya hanyalah profit namun saat ini bisnis dituntut untuk melakukan aktivitas yang mengacu pada konsep sustainable development yakni 3P (profit people dan planet). Pembahasan isu pembangunan berkelanjutan juga diperkenalkan oleh PBB melalui agenda global pembangunan keberlanjutan atau dikenal dengan Sustainable Development Goals (SDGs) pada Tahun 2015 yang terdiri dari 17 tujuan dan 169 target yang diharapkan dicapai pada 2030 (UN, 2015). Kesepakatan yang disetuji oleh negara anggota termasuk Indonesia tersebut menghimbau seluruh dunia untuk mempraktekkan dan melakukan aktivitas yang memperhatikan unsur keberlanjutan.

Himbauan melakukan produksi secara berkelanjutan disambut positif oleh masyarakat dunia khususnya konsumen, sehingga menciptakan iklim produksi yang baru untuk mendukung memproduksi barang yang memiliki jaminan keberlanjutan. Demi meyakinkan konsumen hingga Tahun 2012, sebanyak 435 produk dari berbagai perusahaan sudah memiliki eco-labeling dan akan terus bertambah berdasarkan trend-nya (COSA, 2013). Sektor pertanian sebagai aktivitas produksi di Indonesia juga menjadi sasaran penerapan praktik-praktik berkelanjutan. Mekanisme agribisnis harus diciptakan sedemikian rupa untuk menciptakan iklim bisnis yang mampu diterima sehingga produk pertanian tidak kehilangan pasarnya akibat dari kehilangan kepercayaan konsumen. Salah satu komoditas pertanian yang sering mendapat perhatian terhadap pemenuhan kriteria keberlanjutan oleh konsumen adalah produk kelapa sawit.

Kelapa sawit merupakan komoditas ekspor utama yang memiliki banyak manfaat bagi perekonomian Indonesia. Pembangunan perkebunan kelapa sawit dimulai pada Tahun 1969 dimulai ketika pemerintah Indonesia membentuk perusahaan negara perkebunan (PNP) dengan awal pendanaan investasi oleh Bank Dunia (World Bank) dan Bank Pembangunan Asia (The Asian Development Bank). Sejak awal pertumbuhan kelapa sawit di Indonesia pada tahun 1970-an perkebunan kelapa sawit masih didominasi oleh perkebunan besar baik swasta maupun negara. Dilihat dari pertumbuhan rata-rata perkebunan kelapa sawit sebesar 10,99\% pada periode 1998-2016. Pada Tahun 1980 luas areal perkebunan kelapa sawit Indonesia sebesar 294,56 ribu hektar maka pada Tahun 2015 telah mencapai 11,30 juta hektar. Pertumbuhan produksi mengikuti luas areal kelapa sawit sebesar 11,50\% (Kementerian Pertanian 2017). Tahap perkembangan perkebunan kelapa sawit mengalami pergeseran dimana pada perkebunan rakyat telah mendominasi kepemilikan lahan perkebunan kelapa sawit. Luas perkebunan kelapa sawit rakyat mencapai $41 \%$ dari luas keseluruhan kebun kelapa sawit di Indonesia dengan jumlah pekebun yang terlibat mencapai 2,2 juta (Direktorat Jenderal Perkebunan, 2014).

Provinsi Jambi termasuk sepuluh besar provinsi produsen kelapa sawit Indonesia ditinjau dari luas dan produksinya. Perkebunan kelapa sawit berkembang pesat era 1980-1990 dimana terjadi fenomena transmigrasi dari Pulau Jawa ke Pulau Sumatera yang sebagian besar penduduk mengusahakan perkebunan kelapa sawit sebagai komoditas penopang perekonomian keluarga. Perkebunan kelapa sawit di Provinsi Jambi diusahakan secara mandiri maupun bermitra keperusahan. Supriadi (2013) menyatakan bahwa pembangunan perkebunan kelapa sawit telah menimbulkan mobilitas penduduk yang tinggi sehingga daerah-daerah sekitar pembangunan perkebunan muncul pusat-pusat pertumbuhan ekonomi di pedesaan kondisi ini menyebabkan meningkatnya daya beli masyarakat pedesaan terutama terhadap kebutuhan rutin rumah tangga dan kebutuhan sarana produksi perkebunan kelapa sawit. Perkebunan kelapa sawit rakyat di Provinsi 
Jambi secara ekonomi mampu meningkatkan pendapatan masyarakat dilihat dari pertumbuhan sebelum dan sesudah perkebunan kelapa sawit berkembang. Luas perkebunan kelapa sawit Provinsi Jambi berdasarkan kepimilikan didominasi perkebunan rakyat sementara perkembangan perkebunan negara cenderung stabil namun perkebunan rakyat cenderung meningkat. Berdasarkan data (BPS, 2018) sekitar 75 persen perkebunan kelapa sawit di Provinsi Jambi berdasarkan penguasaan adalah perkebunan kelapa sawit rakyat. Luas lahan perkebunan kelapa sawit rakyat pada Tahun 2017 lebih dari 500 ribu hektar jumlah ini akan semakin bertambah dengan melihat antusias masyarakat terhadap bisnis perkebunan kelapa sawit.

Perkebunan kelapa sawit rakyat merupakan bagian dari rantai pasok agribisnis kelapa sawit yang perlehan dituntut untuk menerapkan aspek keberlanjutan. Sertifikasi keberlanjutan seakan menjadi kewajiban untuk memasuki pasar sementara posisi perkebunan yang tidak memiliki kemampuan manajerial menjadi keterbatasan bagi petani. Pemenuhan aspek keberlanjutan terhadap perkebunan kelapa sawit rakyat bukan hal yang mudah karena motif ekonomi masih mendominasi dalam praktik budidaya perkebunan kelapa sawit rakyat namun hal ini tidak menjadi alasan bagi pihak pengambil kebijakan untuk mewujudkan perkebunan kelapa sawit rakyat berkelanjutan.

Perkebunan kelapa sawit berkelanjutan merupakan penerapan dari konsep pertanian berkelanjutan, yaitu sistem pertanian yang berorientasi pada keseimbangan ekonomi, sosial, dan ekologi. Tuntutan tersebut direspons melalui penerapan RSPO dan ISPO dalam perkebunan kelapa sawit. Namun, sejauh ini masih banyak perkebunan yang belum berkelanjutan sehingga dampak negatif dari perkebunan kelapa sawit masih dirasakan di berbagai daerah. Bencana asap sebagai dampak kebakaran lahan di area perkebunan kelapa sawit, penggunaan pekerja anak, konflik lahan, dan rendahnya kesejahteraan tenaga kerja merupakan implikasi dari perkebunan yang tidak berkelanjutan (Ngadi, 2015).

Keberlanjutan sebagai suatu gagasan yang normatif tentang peranan manusia dalam bertindak terhadap alam, dan bertanggung jawab terhadap satu sama lain dan masa depan generasi (Baumgärtner et al. 2010). Pembangunan berkelanjutan merupakan sebuah proses perubahan dalam perkembangan yang membutuhkan sumber daya, investasi, teknologi, dan kelembagaan (Deng, 2015). Munashinghe (1993) dalam Nurmalina (2008) menggambarkan pembangunan keberlanjutan sebagai interaksi antar tiga dimensi, yaitu dimensi ekologi, sosial dan ekonomi. Inti konsep keberlanjutan adalah bahwa tujuan ekonomi, sosial, dan lingkungan harus saling terkait dan saling mendukung dalam proses pembangunan berkelanjutan. Ordóñez et al. (2010) menjelaskan bahwa pembangunan berkelanjutan adalah sebuah kapasitas dalam memelihara stabilitas ekologi, sosial dan ekonomi dalam transformasi jasa biosfir kepada manusia, pembangunan keberlanjutan mampu memenuhi dan optimasi kebutuhan pada saat ini dan generasi mendatang dalam waktu tak terbatas. Dengan demikian, konsep keberlanjutan setidaknya dapat dilihat dari tiga aspek namun dapat disesuaikan berdasarkan permasalahan penelitian yang akan dikaji.

Penelitian ini mengkaji keberlanjutan berdasarkan lima dimensi yakni ekonomi, sosial, lingkungan, kelembagaan, dan teknologi. Dimensi tersebut digunakan untuk melihat kondisi keberlanjutan perkebunan kelapa sawit sebagai mata pencaharian masyarakat. Indikator penilaian keberlanjutan perkebunan kelapa sawit yang digunakan dalam penelitian ini adalah berdasarkan prinsip dan kriteria keberlanjutan perkebunan kelapa sawit rakyat oleh RSPO (Roundtable Sustainability Palm Oil) dan ISPO (Indonesian Sustainability Palm Oil).

Tujuan dari penelitian ini adalah (1) menilai indeks dan status keberlanjutan perkebunan kelapa sawit rakyat Provinsi Jambi; (2) menilai indeks dan status keberlanjutan masing-masing dimensi (ekonomi, sosial, 
lingkungan, kelembagaan, dan teknologi) serta mengidentfikasi atribut yang sensitif berpengaruh pada keberlanjutan perkebunan kelapa sawit rakyat.

Manfaat dari penelitian ini melalai pendekatan Multi Dimensional Scalling (MDS) pada masing-masing dimensi sebagai evaluasi pembangunan keberlanjutan perkebunan kelapa sawit rakyat Provinsi Jambi. Atribut sensitif yang mempengaruhi keberlanjutan perkebunan kelapa sawit pada penlitian ini mampu digunakan untuk fokus mengembangkan keberlanjutan perkebunan kelapa sawit rakyat.

\section{METODE}

\section{PENGUMPULAN DATA DAN ANALISIS}

Penelitian keberlanjutan perkebunan kelapa sawit rakyat dilakukan di Provinsi Jambi pada dua kabupaten yakni Kabupaten Merangin dan Kabupaten Muaro Jambi. Kabupaten tersebut dipilih sebagai kabupaten sentra perkebunan kelapa sawit berdasarkan luas lahan. Kabupaten Muaro Jambi terdiri dari 15 kecamatan dan Kabupaten Merangin terdiri dari 24 kecamatan. Terdapat dua kecamatan di Kabupaten Muaro Jambi yang menjadi lokasi penelitian adalah Kecamatan Kumpeh Ulu mewakili perkebunan kelapa sawit rakyat yang bermitra dengan perusahaan, Kecamatan Sungai Bahar mewakili perkebunan kelapa sawit rakyat yang tidak bermitra, dan satu kecamatan di Kabupaten Merangin yakni Tabir Selatan sebagai perkebunan rakyat yang telah tersertifikasi RSPO.

Penentuan sampel penelitian dilakukan secara purposive dengan pertimbangan pengelompokan sampel (stratified sampling) berdasarkan karakteristik dan sistem usaha perkebunan. Sampel berjumlah 99 petani yang terdiri dari ketua Gapoktan, ketua kelompok tani, pengurus koperasi, dan petani sebagai anggota kelompok tani biasa yang tidak memegang jabatan dikelompok tani.

Data utama yang digunakan adalah data primer dan didukung dengan data sekunder.
Data primer diperoleh dari hasil wawancara langsung kepada petani sampel pada daerah penelitian sedangkan data sekunder diperoleh dari Badan Pusat Statistik (BPS) Provinsi Jambi, dinas perkebunan Provinsi Jambi, dan instansi terkait lainnya. Penelitian ini menggunakan metode analisis teknik ordinasi Rap-palmoil melalui metoda Multi Dimensional Scalling (MDS) untuk menilai indeks dan status keberlanjutan perkebunan kelapa sawit rakyat, serta mengidentifikasi atribut sensitif yang berpengaruh terhadap indeks keberlanjutan perkebunan kelapa sawit rakyat masing-masing dimensi melalui analisis leverage. Keberlanjutan perkebunan kelapa sawit rakyat pada penelitian ini melalui lima pendekatan yakni dimensi ekonomi, sosial, lingkungan, kelembagaan, dan teknologi. Masing-masing dimensi terdiri dari 9-10 atribut. Secara terstruktur tahapan penelitian dapat dilihat pada Gambar 1 berikut ini :

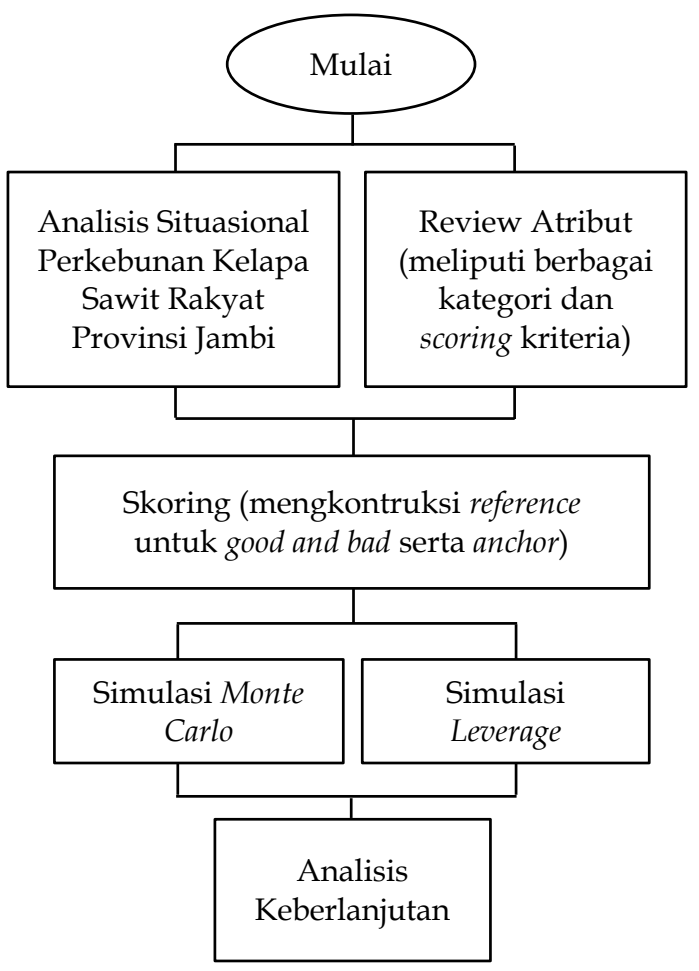

\section{Gambar 1. Tahapan Analisis}

Teknik statistik yang digunakan dalam penelitian ini adalah teknik Rap-Palmoil melalui metode Multi Dimensional Scalling (MDS) dari transformasi multidimensi men- 
jadi sederhana (Fauzi dan Anna, 2005). Teknik ordinasi Rap-Palmoil ini merupakan modifikasi dari Rapfish yang dikembangkan oleh University of Columbia untuk menilai keberlanjutan perikanan laut. Analisis ordinasi rappalmoil dilakukan melalui beberapa tahapan yaitu: (1) penentuan atribut berdasarkan penelitian terdahulu dan penilaian keberlanjutan perkebunan kelapa sawit rakyat pada prinsip dan kriteria RSPO (2018) dan ISPO (2015), pada penelitian ini terdapat 48 atribut mencakup lima dimensi yaitu ekonomi ( 9 atribut), sosial (10 atribut), lingkungan (9 atribut), kelembagaan (10 atribut), dan teknologi (10 atribut); (2) penilaian setiap atribut dalam skala ordinal (skoring) berdasarkan kriteria keberlanjutan setiap dimensi; (3) analisis rap-palmoil dengan metoda MDS; (4) menilai indeks dan status keberlanjutan perkebunan kelapa sawit rakyat yang dikaji pada level multidimensi maupun masingmasing dimensi; (5) analisis sensitivitas (leverage analysis) untuk menentukan atribut yang sensitif memepengaruhi keberlanjutan perkebunan kelapa sawit rakyat; (6) monte carlo analysis untuk memperhitungkan aspek ketidakpastian (Kavanagh, 2001; Pitcher and David, 2001).

Fauzi dan Anna (2002) menyatakan bahwa analisis dengan MDS dalam RAPFISH memberikan hasil yang stabil jika dibandingkan dengan metode multi variate analysis yang lain. Dalam MDS, dua titik atau objek yang sama dipetakan dalam satu titik yang saling berdekatan. Sebaliknya, obyek atau titik yang tidak sama digambarkan dengan titik-titik yang berjauhan. Teknik ordinasi atau penentuan jarak di dalam MDS didasarkan pada euclidian distance atau teknik penentuan jarak antar atribut antara nilai baik (good) dan buruk (bad) yang ditetapkan pada pemberian nilai skor, yang dalam ruang berdimensi dan persamaannya adalah:

$d=\sqrt{\left(x_{1}-\left.x_{2}\right|^{2}+\left|y_{1}-y_{2}\right|^{2}+z_{1}-\left.z_{2}\right|^{2}+\cdots\right)}$

Ordinasi dari obyek atau titik tersebut kemudian diaproksimasi dengan meregresikan jarak euclidian $\left(d_{i j}\right)$ dari titik i ke titik $\mathrm{j}$ dengan titik asal $\left(\delta_{i j}\right)$. Sebagaimana dengan persamaan:

$$
d_{i j}=\propto+\beta \delta i j+\varepsilon
$$

Untuk meregresikan persamaan jarak euclidian tersebut, digunakan metode last squared bergantian berdasarkan akar Euclidian Distance (square distance) atau disebut dengan metode ALSCAL. Kavanagh dan Pitcher (2004) menyatakan bahwa metode ini mengoptimalkan jarak kuadrat (squared distance $=$ $d_{i j k}$ ) terhadap data kuadrat (titik asal $=\mathrm{O}_{\mathrm{ijk}}$ ). Dalam lima dimensi $(\mathrm{i}, \mathrm{j}, \mathrm{k}, \mathrm{l}, \mathrm{m})$ disebut $\mathrm{S}$-Stress, sesuai dengan persamaan:

$$
S=\sqrt{\frac{1}{m} \sum_{k=1}^{m}\left[\frac{\sum_{t} \sum_{f}\left(d_{i j k l m}^{2}-0_{i j k l m}^{2}\right)^{2}}{\sum_{t} \sum_{f} 0_{i j k l m}^{4}}\right]}
$$

Jarak kuadrat merupakan jarak Euclidian, sesuai dengan persamaan :

$$
d_{i j k l m}^{2}=\sum w k a\left(x_{i a}-x_{j a}\right)^{2}
$$

Melalui metode analisis MDS, maka posisi titik keberlanjutan dapat divisualisasikan melalui sumbu horizontal dan sumbu vertikal yang digambarkan oleh analisis leverage dan analisis monte carlo. Analisis leverage dilakukan untuk mengetahui indikator yang sensitif dalam mempengaruhi keberlanjutan. Menurut Hidayanto et al. (2009) dan Kusbimanto et al. (2013), analisis sensitivitas (leverage) dalam MDS dilakukan untuk mengetahui indikator kunci. Indikator kunci (atribut sensitif) diperoleh berdasarkan hasil analisis leverage yang terlihat pada perubahan Root Mean Square (RMS) ordinasi pada sumbu $X$. Semakin besar perubahan RMS, maka semakin sensitif peranan indikator tersebut terhadap peningkatan status keberlanjutan. Analisis selanjutnya yaitu analisis ketidakpastian (montecarlo). Analisis monte carlo merupakan analisis untuk menduga pengaruh galat (error) acak dalam proses analisis yang dilakukan pada selang kepercayaan 95\%. Selain itu terdapat analisis monte carlo untuk memperhitungkan aspek ketidakpastian (Nurmalina, 2008). 
Setelah dilakukan ordinasi, kemudian dilakukan penilaian goodness of fit yaitu jarak titik pendugaan dengan titik asal. Nilai goodness of fit mencerminkan besaran nilai S-Stress dari $R^{2}$. Menurut Kavanagh dan Pitcher (2004), model yang baik jika nilai S-Stress kurang dari $0.25(\mathrm{~S}<0.25)$, dan R2 mendekati 1 $(100 \%)$. Nilai stress dan koefisien determinasi $\left(R^{2}\right)$ menentukan perlu tidaknya penambahan peubah untuk memastikan bahwa peubah yang digunakan telah mewakili sifat obyek yang dibandingkan. Skala indeks keberlanjutan sistem dikaji pada penelitian ini memiliki selang 0 - 100 persen dan terdapat empat kategori status keberlanjutan seperti pada Tabel 1.

\section{HASIL DAN PEMBAHASAN}

\section{ANALISIS KEBERLANJUTAN PERKEBUNAN KELAPA SAWIT RAKYAT PROVINSI JAMBI MULTIDIMENSI}

Hasil analisis Rap-Palmoil secara multidimensi dengan menggunakan metode multidimensional scalling menghasilkan nilai indeks keberlanjutan perkebunan kelapa sawit Provinsi Jambi (IKB-palmoil) sebesar 57,79 pada skala keberlanjutan 0-100, termasuk dalam kategori "cukup berkelanjutan" dengan nilai S-Stress 0,198 dan $\mathrm{R}^{2}$ 0,90 telah memenuhi goodnees of fit secara statistik.

Berdasarkan hasil analisis, skala keberlanjutan perkebunan kelapa sawit Provinsi Jambi dilihat dari multidimensi (IKB-PalmOil $=57.79)$ termasuk dalam katogeri cukup berkelanjutan. Analisis ini merupakan gabungan antara seluruh dimensi (ekonomi, sosial, lingkungan, kelembagaan, dan teknologi) yang disebut dengan analisis multidimensi. Masing-masing dimensi memiliki atribut yang menjadi tolak ukur keberlanjutan perkebunan kelapa sawit di Provinsi Jambi (Gambar 2).

Kelapa sawit merupakan komoditas strategis di Provinsi Jambi, menjadi komoditas unggulan sehingga berbagai pihak mengupayakan keberlanjutan perkebunan kelapa sawit. Berbagai peran pemerintah dan swasta pada perkebunan kelapa sawit rakyat adalah melalui pola kemitraan, penyediaan layanan

Tabel 1. Kategori Indeks dan Status Keberlanjutan Perkebunan Kelapa Sawit Provinsi Jambi

\begin{tabular}{cc}
\hline Nilai indeks & Kategori status \\
\hline $0,00-25,00$ & Buruk; tidak berkelanjutan \\
$25,01-50,00$ & Kurang; kurang berkelanjutan \\
$50,01-75,00$ & Cukup; cukup berkelanjutan \\
$75,01-100,00$ & Baik; sangat berkelanjutan \\
\hline
\end{tabular}

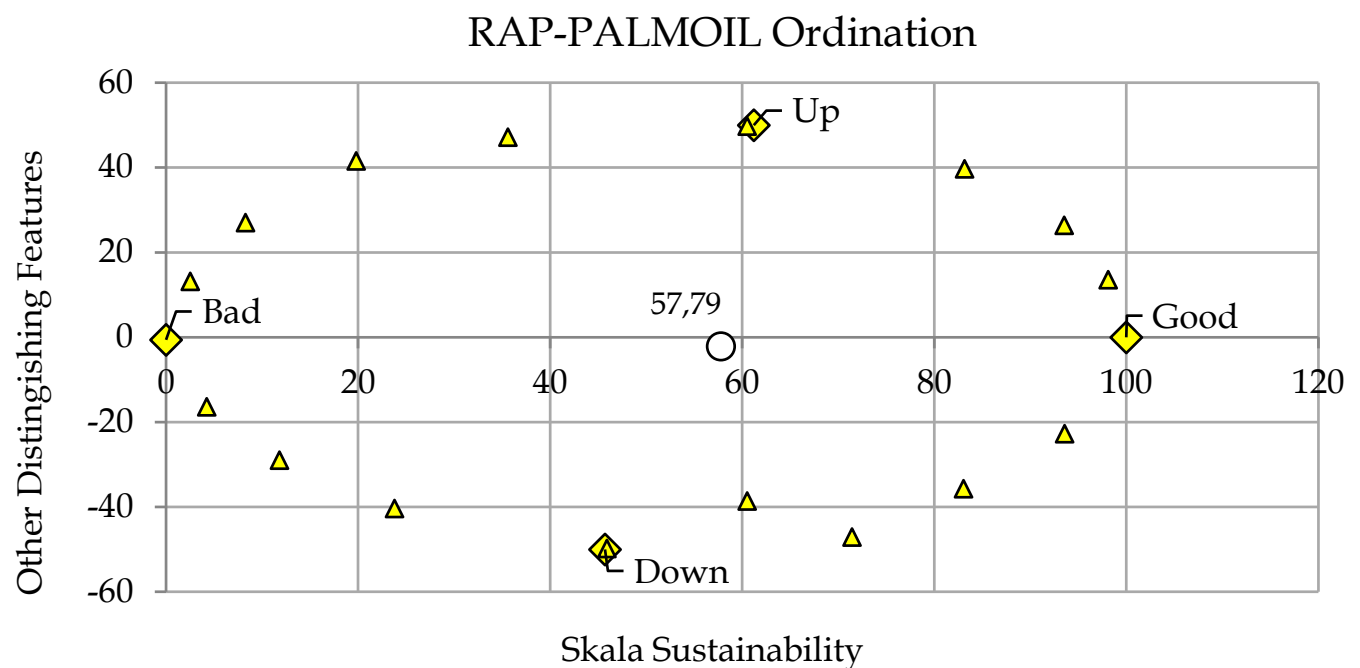

Gambar 2. Skala Keberlanjutan Perkebunan Kelapa Sawit Rakyat Provinsi Jambi 
penyuluhan, bantuan modal peremajaan, dan informasi harga TBS.

Kebijakan pemerintah Provinsi Jambi bagi pengembangan komoditas kelapa sawit adalah terfokus pada peningkatan kapasitas kelembagaan dan peremajaan dengan kemitraan melalui program Sistem Kebersamaan Ekonomi. Berdasarkan Kemitraan (SKE-BK), program ini diharapkan mampu meningkatkan partisipasi petani dalam melakukan praktik-praktik usaha perkebunan kelapa sawit yang saling menguntungkan antara pemerintah, swasta, dan petani swadaya. Sedangkan program peremajaan di fokuskan pada perkebunan dengan usia tua atas sinergi kepada BDPPKS.

Hidayanto (2009) melakukan penelitian mengenai keberlanjutan kakao di provinsi Kalimantan Timur, nilai keberlanjutan perkebunan kakao nilai keberlanjutan komoditas perkebunan kakao pada berbagai dimensi adalah $36,39-75,20$ nilai yang variatif dengan nilai terendah adalah dimensi teknologi dan nilai tertinggi adalah dimensi sosial. Berdasarkan kisaran nilai keberlanjutan pada beberapa komoditas diatas nilai komoditas perkebunan kelapa sawit rakyat Provinsi Jambi sebesar 57,79 termasuk pada kategori "cukup berkelanjutan" dapat dikatakan tidak terlalu buruk namun perlu peningkatan pada beberapa atribut yang akan dibahas selanjutnya.

Nilai IKB-Palmoil diperoleh berdasarkan penilaian terhadap 48 atribut keberlanjutan yang tercakup pada lima dimensi. Hasil analisis ke lima dimensi tersebut adalah indeks keberlanjutan pada masing-masing dimensi adalah dimensi ekonomi 54,11 (cukup berkelanjutan), dimensi sosial 66,83 (cukup berkelanjutan), dimensi lingkungan 58,65 (cukup berkelanjutan), dimensi kelembagaan
46,41 (kurang berkelanjutan), dimensi teknologi 57,80 (kurang berkelanjutan) dapat dilihat secara diagram layang pada (Gambar 3).

Dapat dilihat bahwa dimensi kelembagaan memiliki nilai keberlanjutan paling rendah, kemudian dimensi ekonomi, dimensi teknologi, dimensi lingkungan, dan dimensi sosial dengan nilai yang paling tinggi. Nilai indeks keberlanjutan seluruh dimensi masuk kedalam kategori kurang-cukup keberlanjutan, hanya satu dimensi masuk ke dalam kategori kurang berkelanjutan yakni dimensi kelembagaan.

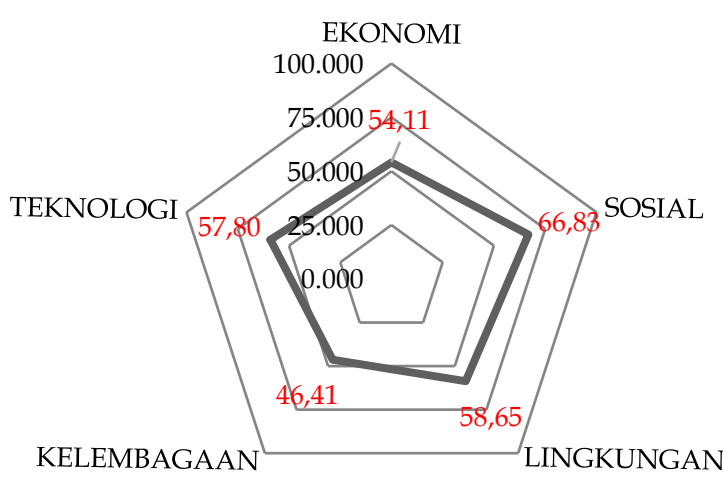

\section{Gambar 3. Diagram Layang Indeks \\ Keberlanjutan Perkebunan Kelapa Sawit Rakyat}

Hasil analisis memperlihatkan nilai Sstress yang dihasilkan pada setiap dimensi maupun multidimensi memiliki nilai yang lebih kecil dari ketentuan $(>0,25)$, semakin kecil dari 0,25 semakin baik (Tabel 2). Sedangkan koefisien determinasi $\left(R^{2}\right)$ di setiap dimensi dan multidimensi semua nilainya mendekati 1, dengan demikian dari kedua parameter statistik ini menunjukkan bahwa seluruh atribut yang digunakan dan dianalisis secara dimensi atapun multidimensi sudah memenuhi kriteria statistik dan layak mene-

Tabel 2. Goodness of Fit dari Analisis Indeks dan Status Keberlanjutan Perkebunan Kelapa Sawit Rakyat Provinsi Jambi

\begin{tabular}{lccccc}
\hline Wilayah & Nilai MDS & Monter Carlo & Perbedaan & S-Stress & $\mathbf{R}^{\mathbf{2}}$ \\
\hline Multidimensi & 57,795 & 56,839 & 0,956 & 0,198 & 0,901 \\
Ekonomi & 54,111 & 53,119 & 0,992 & 0,217 & 0,897 \\
Sosial & 66,831 & 65,864 & 0,967 & 0,230 & 0,887 \\
Lingkungan & 58,645 & 57,722 & 0,954 & 0,227 & 0,854 \\
Kelembagaan & 46,405 & 45,482 & 0,923 & 0,152 & 0,911 \\
Teknologi & 57,795 & 56,884 & 0,911 & 0,223 & 0,870 \\
\hline
\end{tabular}


rangkan keberlanjutan perkebunan kelapa sawit rakyat Provinsi Jambi.

Berdasarkan Tabel 2 dapat dilihat bahwa nilai indeks keberlanjutan perkebunan kelapa sawit rakyat pada selang kepercayaan 95 persen didapatkan hasil selisih antara nilai IKB Rap-Palmoil dan nilai monte carlo sebesar 0,956 (tidak lebih besar dari satu). Nilai selisih yang kecil menandakan bahwa sistem yang dikaji memiliki tingkat kepercayaan yang tinggi. Hasil uji ststistik menunjukkan bahwa metode Rap-Palmoil yang dipilih pada penelitian ini dapat dipertanggungjawabkan secara statistik dan dapat digunakan sebagai salah satu alat evaluasi keberlanjutan perkebunan rakyat khususnya di Provinsi Jambi.

\section{KEBERLANJUTAN PERKEBUNAN KALAPA SAWIT RAKYAT PROVINSI JAMBI MASING-MASING DIMENSI}

Teknik ordinasi Rap-Palmoil melalui metode MDS selain menilai indeks dan status perkebunan kelapa sawit rakyat secara multidimensi juga dapat mengindentifikasi atribut sensitif yang berpengaruh terhadap indeks keberlanjutan perkebunan kelapa sawit rakyat masing-masing dimensi melalui leverage analysis. Hasil analisis Rap-Palmoil dan leverage pada setiap dimensi adalah sebagai berikut:

\section{Keberlanjutan Perkebunan Kelapa Sawit Rakyat Provinsi Jambi Dimensi Ekonomi}

Hasil penelitian sebagaimana terlihat pada Gambar 4 menunjukkan bahwa indeks keberlanjutan perkebunan kelapa sawit rakyat dimensi eknonomi sebesar 54,11 berdasarkan nilai indeks keberlanjutan dimensi ekonomi maka sejalan dengan nilai indeks pada multisimensi, nilai indeks keberlanjutan dimensi ekonomi termasuk dalam ketegori cukup berkelanjutan.

Secara ekonomi perkebunan kelapa sawit rakyat memberikan nilai positif dari segi ekonomi dengan mengurani kemiskinan bagi masyarakat petani perkebunan kelapa sawit. Pada penelitian Supriadi (2013) bahwa perkembangan kelapa sawit di kabupaten sambas berdampak positif pada perekonomian dengan meningkatkan daya beli masyarakat pedesaan. Memiliki multiplier effect, terutama dalam lapangan pekerjaan dan peluang usaha akibat perputaran uang yang terjadi pada daerah tersebut. Berdasarkan indeks dan status keberlanjutan tersebut dimensi ekonomi perlu ditingkatkan lagi mengingat bahwa terdapat beberapa hal yang perlu dievaluasi berdasarkan hasil analisis leverage pada Gambar 4.

Berdasarkan hasil leverage analysis keberlanjutan perkebunan kelapa sawit Provinsi Jambi dimensi ekonomi terlihat pada gambar

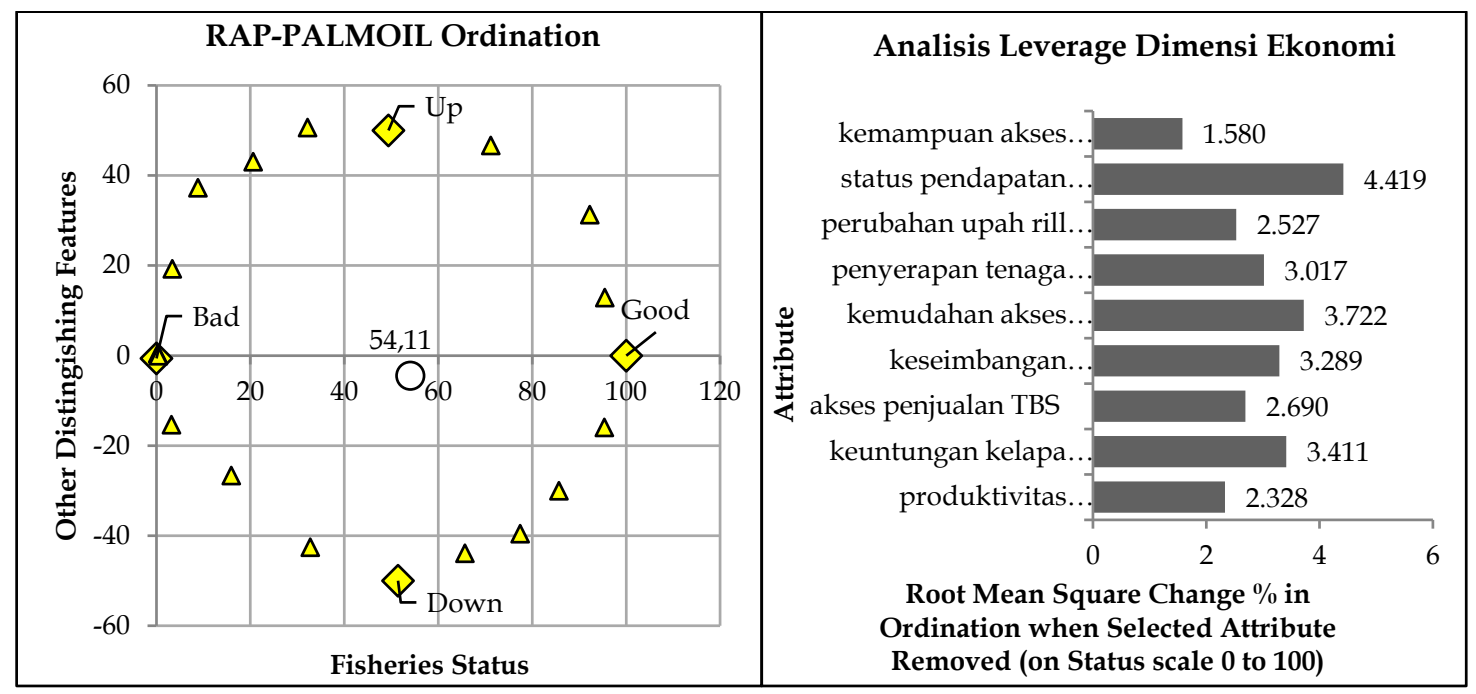

Gambar 4. Analisis Indeks Keberlanjutan Perkebunan Kelapa Sawit Rakyat Provinsi Jambi dan Faktor yang Paling Sensitif Mempengaruhi Keberlanjutan Dimensi Ekonomi 
diketahui bahwa dari 9 atribut yang dianalisis ada 3 atribut yang sensitif mempengaruhi keberlanjutan perkebunan kelapa sawit rakyat antara lain: (1) sistem pendapatan perkebunan kelapa sawit bagi petani, (2) kemudahan akses informasi harga, (3) keseimbangan distribusi keuntungan. Dengan demikian atribut-atribut tersebut perlu diperhatikan dan dikelola dengan sedemikian rupa untuk keberlanjutan perkebunan kelapa sawit rakyat Provinsi Jambi.

Atribut pertama yang paling mempengaruhi keberlanjutan perkebunan kelapa sawit Provinsi Jambi pada dimensi ekonomi adalah status pendapatan perkebunan kelapa sawit bagi petani. Status pendapatan perkebunan kelapa sawit dinilai berdasarkan apakah sebagai sumber pendapatan utama atau terdapat sumber pendapatan lainnya. Ratarata petani perkebunan kelapa sawit di Provinsi Jambi menjadikan kelapa sawit menjadi sumber pendapatan utama dan hanya bergantung kepada penjualan Tandan Buah Segar (TBS) dari perkebunan milik mereka. Berdasarkan penelitian Andriani (2017) menyatakan bahwa petani yang memiliki sumber pendapatan lain (nafkah ganda) memiliki penghasilan yang lebih rendah daripada petani yang hanya fokus kepada perkebunan sawit sehingga petani cenderung tidak memiliki sumber pendapatan lain diluar usaha perkebunan kelapa sawit.

Petani perkebunan kelapa sawit di Provinsi Jambi cenderung tidak memiliki sumber pendapatan lain karena tidak ada keahlian lain diluar dari pertanian perkebunan kelapa sawit. Pendapatan dari usaha perkebunan kelapa sawit berkisar pad Rp $16 \mathrm{jt}-\mathrm{Rp} 25 \mathrm{jt}$ per hektar per tahun dan petani memiliki lahan berkisar 2-5 Ha sehingga dirasa cukup untuk memeniuhi kebutuhan bagi rumah tangga. Namun apabila pengelolaan pendapatan perkebunan kelapa sawit tidak dikelola dengan baik maka akan mengancam keberlanjutan perkebunan kelapa sawit rakyat dari dimensi ekonomi apabila tidak efisien pada persiapan input dan peremajaan.
Atribut lainnya adalah akses informasi harga. Akses informasi harga diperlukan petani bagi penentuan penjualan TBS ke pabrik yang membeli dengan harga tertinggi. Kemudahan akses informasi harga secara transparan dari pemerintah maupun swasta akan membantu petani dalam mempertimbangkan penjualan terkait jarak tempuh kebun-pabrik dan resiko lainnya. Berkaitan dengan atribut sensitif ketiga yakni keseimbangan distribusi keuntungan yang berhubungan dengan rantai penjualan TBS. Petani diharapkan mampu mengakses sampai penjualan ke pabrik secara langsung namun terkadang petani tidak memiliki pilihan lain untuk menjual TBS kepada "tengkulak" dengan marjin harga tertentu dari pabrik. Kondisi ini akibat dari waktu panen yang tidak seragam pada daerah yang sama sehingga membuat ongkos pengiriman akan lebih besar untuk mengantar langsung ke pabrik sehingga menjual kepada tengkulak. Kondisi ini terjadi mengingat untuk mempertahankan mutu TBS harus dalam kondisi segar sampai ke pabrik untuk diolah.

\section{Keberlanjutan Perkebunan Kelapa Sawit Rakyat Provinsi Jambi Dimensi Sosial}

Hasil analisis indeks keberlanjutan perkebunan kelapa sawit rakyat Provinsi Jambi dimensi sosial sebesar 66,83 dengan kategori cukup berkelanjutan. Nilai indeks tersebut dari nilai keberlanjutan pada multidimensi dan dimensi ekonomi. Hal ini mengindikasikan bahwa secara sosial perkebunan kelapa sawit rakyat lebih berkelanjutan dari aspek ekonomi. Berdasarkan hasil analisis leverage dapat diketahui bahwa atribut sensitif yang paling mempengaruhi keberlanjutan perkebunan kelapa sawit rakyat Provinsi Jambi adalah: (1) akses kesehatan; (2) pandangan masyarakat terhadap perkebunan kelapa sawit; (3) akses pendidikan, dapat dilihat pada Gambar 5 .

Akses kesehatan merupakan atribut yang paling sensitif pada dimensi sosial pada keberlanjutan perkebunan kelapa sawit Provinsi Jambi, karena berdasarkan kondisi geografis 


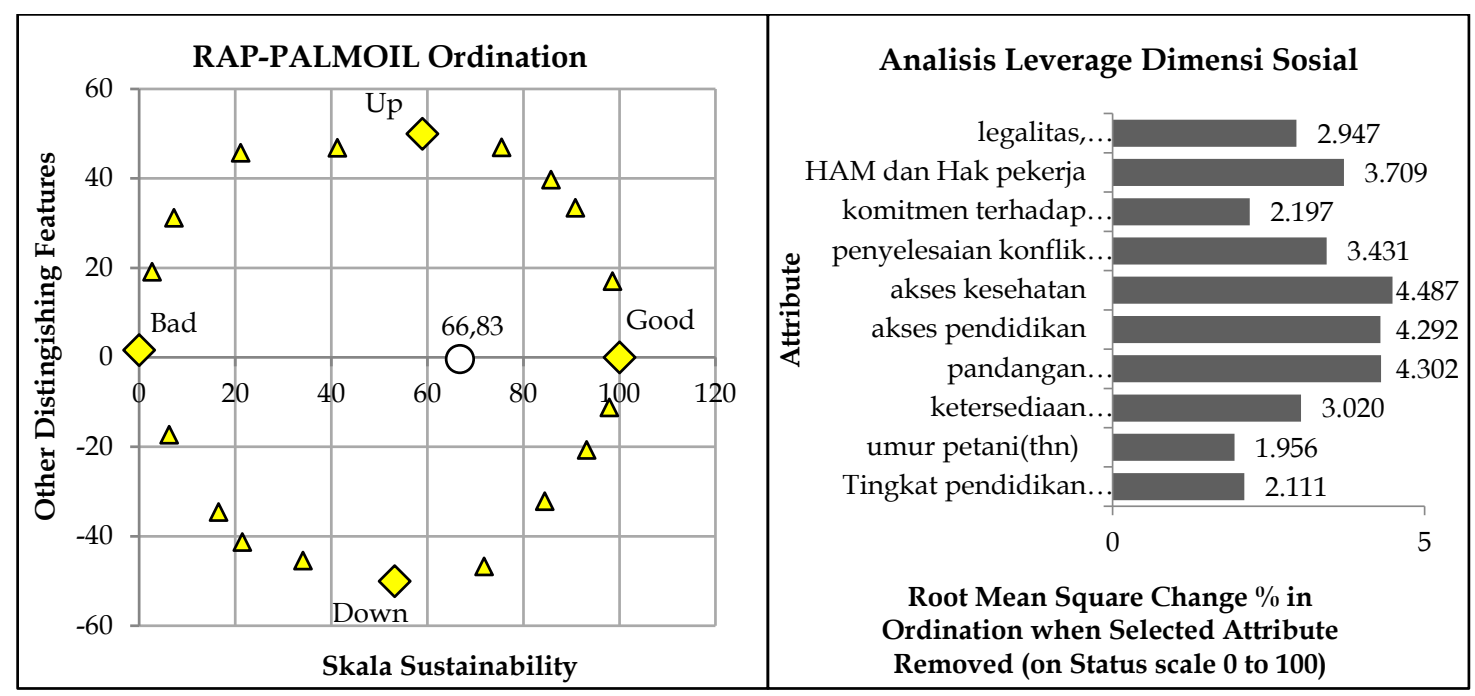

Gambar 5. Analisis Indeks Keberlanjutan Perkebunan Kelapa Sawit Rakyat Provinsi Jambi dan Faktor yang Paling Sensitif Mempengaruhi Keberlanjutan Dimensi Sosial

perkebunan kelapa sawit yang jauh dari perkotaan biasanya sulit untuk mendapatkan akses kesehatan. Hal lain yang dipertimbangkan pada petani dari segi kesehatan adalah penggunaan Alat Pelindung Diri (APD) yang sering diabaikan pekerja khususnya petani swadaya (perkebunan rakyat) akibatnya masih terdapat kecelakaan kerja yang terjadi pada pekerja. Hal ini tentu menjadikan perhatian khusus oleh pemerintah sebagai penyedia layanan jasa kesehatan masyarakat pedesaan karena sulitnya akses kesehatan yang diterima petani sering membuat petani mengambil pengobatan tradisional yang membahayakan kesehatan masyarakat khususnya petani.

Atribut selanjutnya adalah pandangan masyarakat terhadap perkebunan kelapa sawit. Atribut ini mewakili pandangan petani terhadap masyarakat sekitar bagaimana ketertarikan masyarakat kepada usaha perkebunan kelapa sawit. Sebagian besar masyarakat masih sangat tertarik kepada usaha perkebunan kelapa sawit. Tingginya keinginan masyarakat pada usaha perkebunan kelapa sawit juga harus diikuti dengan regulasi yang mumpuni untuk menjamin masyarakat tidak melanggar peraturan dan tetap pada skema perdagangan yang tepat demi menjamin harga.
Faktor lain yang memicu keprihatinan pemerintah terhadap ketertarikan masyarakat terhadap kelapa sawit adalah alih fungsi lahan pangan. Rendahnya pendapatan petani pangan dibanding petani sawit menjadi alasan petani meninggalkan sawah dan beralih ke perkebunan sawit, sebenarnya pemerintah telah melakukan berbagai regulasi melalui PERDA namun inkonsistensi kebijakan pemerintah membuat praktik alih fungsi lahan menjadi tidak terkendali (Daulay et al., 2016).

Akses pendidikan juga merupakan atribut sensitif yang mempengaruhi keberlanjutan perkebunan kelapa sawit pada dimensi sosial. Lokasi perkebunan kelapa sawit di Provinsi Jambi yang jauh dari perkotaan menjadi alasan atribut ini menjadi atibut yang dipertimbangkan pada dimensi sosial. Tiga daerah penelitian pada penelitian ini hanya memiliki akses pendidikan sampai jenjang sekolah dasar, untuk melanjutkan ke sekolah menengah maka anak-anak dari petani menempuh jarak yang cukup jauh atau harus tinggal di dekat perkotaan yang jauh dari tempat tinggal di daerah perkotaan sehingga tidak efisien waktu dan biaya pendidikan yang dikeluarkan. Hal ini seharusnya menjadi perhatian khusus pemerintah untuk menyediakan layanan pendidikan dan kesehatan yang terjangkau oleh 
masyarakat khususnya petani kelapa sawit di pelosok desa.

Atribut sensitif tersebut dapat digunakan sebagai indikator kunci peningkatan keberlanjutan perkebunan kelapa sawit rakyat karena walaupun dimensi sosial merupakan dimensi dengan nilai keberlanjutan tertinggi namun tetap membutuhkan perbaikan.

\section{Keberlanjutan Perkebunan Kelapa Sawit Rakyat Provinsi Jambi Dimensi Lingkungan}

Nilai indeks keberlanjutan perkebunan kelapa sawit rakyat Provinsi Jambi dimensi lingkungan dari hasil analisis ordinasi sebesar 58,64 (Gambar 6) termasuk dalam kategori cukup berkelanjutan. Jika dibandingkan dengan nilai keberlanjutan perkebunan kelapa sawit rakyat multidimensi maka angka pada hasil analisis pada dimensi lingkungan tidak jauh berbeda namun dibawah dari nilai keberlanjutan dimensi sosial. Hal ini mengindikasikan bahwa secara sosial perkebunan kelapa sawit rakyat lebih baik dibanding secara lingkungan.

Banyaknya isu negatif terhadap kelapa sawit yang menyatakan bahwa kelapa sawit menimbulkan efek tidak baik terhadap lingkungan membuat dimensi lingkungan menjadi menarik untuk dibahas. Pada penelitian ini berdasarkan analisis leverage untuk melihat faktor utama yang mempengaruhi keberlanjutan dimensi lingkungan 3 dari 10 atribut yang sensitif mempengaruhi adalah (1) pencemaran lingkungan; (2) penerapan teknis budidaya dan pengangkutan; (3) kesesuaian lahan dan agroklimat. Dengan demikian untuk memenuhi keberlanjutan dimensi lingkungan atribut-atribut tersebut perlu diperhatikan dan dikelola dengan baik dapat dilihat pada Gambar 6.

Atribut sensitif yang mempengaruhi keberlanjutan perkebunan kelapa sawit pada penelitian ini adalah pencemaran lingkungan. Pada penelitian ini jenis pencemaran lingkungan yang disoroti adalah yang kerap terjadi pada perkebunan rakyat antara lain seperti pembuangan limbah cair yang dilakukan, tidak memperhatikan status pencemaran aliran sungai, penggunaan pupuk yang tidak sesuai rekomendasi, dan pada satu wilayah gambut tidak memperhatikan teknis budidaya pada daerah gambut. Sesuai penelitian Utami (2017) menyatakan bahwa di Kabupaten Tanjabtim Provinsi Jambi ekspansi perkebunan kelapa sawit memiliki dampak positif dan negatif. Berdasarkan persepsi masyarakat ekspansi perkebunan kelapa sawit walaupun secara ekonomi meningkatkan pendapatan dan kesejahteraan masyarakat namun pada perkebunan kelapa sawit dapat mengakibatkan dampak negatif terhadap lingkungan berupa berkurangnya

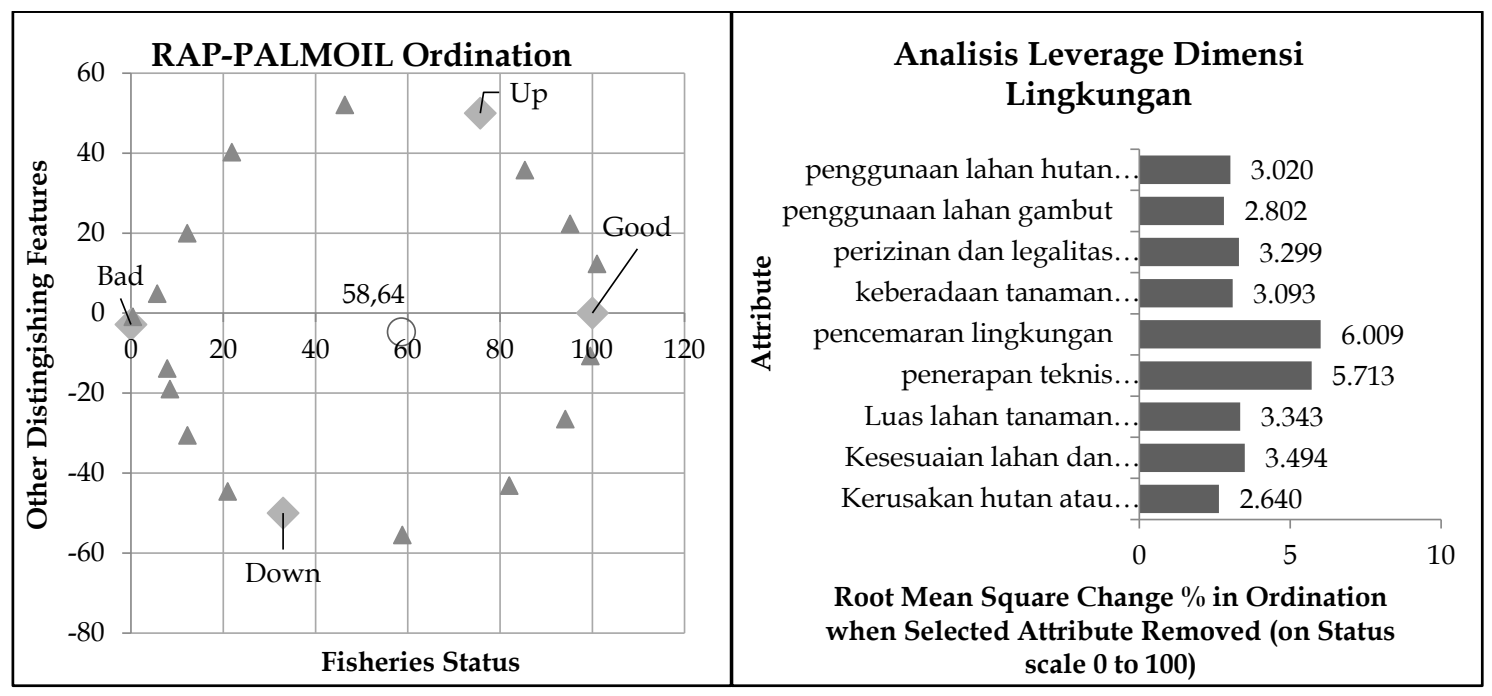

Gambar 6. Analisis Indeks Keberlanjutan Perkebunan Kelapa Sawit Rakyat Provinsi Jambi dan Faktor yang Paling Sensitif Mempengaruhi Keberlanjutan Lingkungan 
kuantitas air tanah, pencemaran air, dan berkurangnya populasi satwa dibandingkan dengan kondisi sebelum adanya ekspansi perkebunan kelapa sawit, sedangkan untuk eksternal akibat limbah cair industri pengolahan CPO sudah diinternalisasikan dengan membuat instalasi pengolahan air limbah (IPAL), namun kondisi saat ini kapasitas IPAL mulai menurun akibatnya limbah cair tidak dapat tertampung dan meluap ke sungai yang mengakibatkan kembali terjadi eksternalitas. Maka perlu adanya regulasi yang mumpuni kepada masyarakat tentang pentingnya menjaga kelestarian lingkungan dalam usaha perkebunan kelapa sawit rakyat.

Atribut sensitif lainnya adalah penerapan teknis budidaya dan pengangkutan serta kesesuaian lahan dengan agroklimat. Penerapan teknis budidaya yang dimaksudkan adalah segala aspek pada teknis budidaya dan pengangkutan berkelanjutan yang digunakan oleh petani. Teknis budidaya yang dilakukan petani beragam disetiap lokasi penelitian. Penilaian pada penelitian ini dilakukan berdasarkan wawancara pada petani tentang teknis budidaya dari pembibitan hingga pemanenan. Item teknis budidaya yang rentan pada kategori keberlanjutan adalah perawatan dan pemupukan karena dibeberapa daerah masih melakukan pembakaran sisa gulma dalam skala kecil, dan membuang sisa bahan kimia sembarangan.
Hal ini disebabkan kurangnya pengetahuan petani tentang teknis budidaya yang baik dan benar. Sementara dengan atribut kesesuaian lahan dengan agroklimat adalah di beberapa tempat petani sudah memperhatikan kesesuaian lahan namun di beberapa titik lainnya petani bahkan tidak mengetahui jenis lahan dan iklim seperti apa yang dimiliki oleh petani daerah tersebut. Sehingga memang sudah sangat penting petani diberikan pemahaman yang tentang budidaya keberlanjutan perkebunan kelapa sawit.

\section{Keberlanjutan Perkebunan Kelapa Sawit Rakyat Provinsi Jambi Dimensi Kelembagaan}

Nilai indeks keberlanjutan perkebunan kelapa sawit rakyat dimensi kelembagaan berdasarkan hasil analisis sebesar 46,40 termasuk dalam kategori kurang berkelanjutan. Nilai keberlanjutan terendah dibandingkan dengan nilai keberlanjutan multidimensi maupun antar dimensi (Gambar 7).

Kelembagaan merupakan faktor penting pada sektor pertanian. Adanya kelembagaan dapat memangkas biaya transaksi dan memudahkan penerapan teknologi. Menurut (Bunch, 1991 dalam Anantayu, 2009) kelembagaan pada pertanian berguna untuk memberikan keberlanjutan pada usaha dan pene-
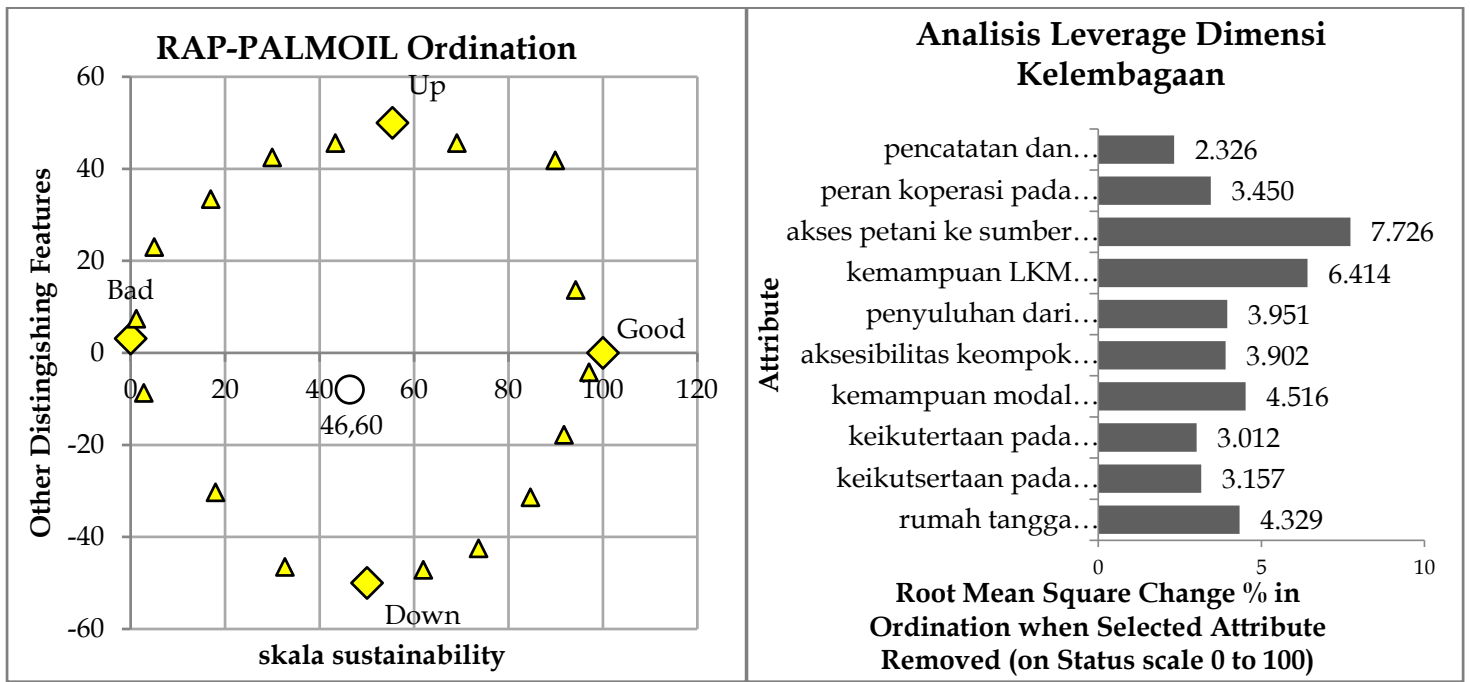

Gambar 7. Analisis Indeks Keberlanjutan Perkebunan Kelapa Sawit Rakyat Provinsi Jambi dan Faktor yang Paling Sensitif Mempengaruhi Keberlanjutan Dimensi Kelembagaan 
rapan teknologi, menyiapkan masyarakat agar mampu bersaing secara ekonomi terbuka

Berdasarkan analisis leverage dapat diketahui bahwa atribut yang berpengaruh sensitif terhadap keberlanjutan perkebunan kelapa sawit rakyat Provinsi Jambi adalah (1) akses petani ke sumber teknologi; (2) kemampuan LKM melayani kebutuhan petani; (3) kemampuan modal kelompok tani.

Peran kelembagaan dibutuhkan oleh petani untuk kemudahan akses dan bantuan. Pemerintah dan swasta dilibatkan dalam peran kelembagaan kepada petani. Berdasarkan hasil penelitian ini dimensi kelembagaan pada perkebunan kelapa sawit rakyat Provinsi Jambi masuk dalam kategori kurang berkelanjutan artinya dimensi kelembagaan kurang berfungsi pada daerah penelitian ini dan apabila dibiarkan seperti kondisi saat ini maka akan berbahaya bagi keberlanjutan perkebunan kelapa sawit rakyat.

Atribut sensitif mempengaruhi keberlanjutan perkebunan kelapa sawit rakyat dimensi kelembagaan adalah akses petani ke sumber teknologi. Atribut ini meliputi jarak antara lokasi kebun dan sumber teknologi, sarana infrastruktur, dan sarana mobilitas petani. Dari hasil penelitian ini dapat dilihat bahwa akses petani ke sumber teknologi belum dapat dikatakan baik karena para petani masih mengeluhkan masalah ruas jalan yang rusak yang membuat jarak tempuh ke sumber teknologi semakin jauh. Serta ketidakmampuan kelompok tani dan pemerintah setempat menampung aspirasi petani terkait hal tersebut membuat permasalahan ini sulit diatasi.

Kemampuan Lembaga Keuangan Mikro (LKM) melayani kebutuhan petani dan kemampuan modal kelompok tani juga termasuk atribut yang sensitif mempengaruhi keberlanjutan dimensi kelembagaan. Pada daerah penelitian permasalahan LKM beragam. Antara LKM dan kelompok tani juga saling memiliki keterkaitan dalam penyediaan layanan keuangan atau modal. KUD yang diharapkan mampu menjadi sarana simpan pinjam dalam kenyataannya hanya sebagai sarana pinjam dan sulit untuk pengembalian sehingga para pengurus dan pemerintah menjadi kewalahan dalam mengatasi masalah ini. Kelompok tani sudah menajalankan tugasnya dengan baik, ada beberapa yang kurang aktif namun masih saling membutuhkan karena aktivitas perkebunan (pemanenan, peralatan, dan pemupukan) membutuhkan kelompok tani untuk mengatur jadwal dan pengangkutan. Namun kelompok tani tidak bisa menjadi saran penjamin modal kepada pihak perbankan ataupun KUD. Peran kelompok tani dari segi keuangan kepada pengajuan modal kepada pemerintah seperti bantuan modal peremajaan yang sedang berlangsung antara kelompok tani di Sungai Bahar dan pemerintah (BPDPKS). Untuk meningkatkan peran kelembagaan pada perkebunan kelapa sawit rakyat yang sensitif untuk keberlanjutan adalah peran pemerintah dan LKM dari segi keuangan atau jaminan modal.

\section{Keberlanjutan Perkebunan Kelapa Sawit Rakyat Provinsi Jambi Dimensi Teknologi}

Nilai keberlanjutan perkebunan kelapa sawit rakyat Provinsi Jambi dimensi teknlogi pada penelitian ini adalah 59,02 termasuk dalam kategori cukup berkelanjutan. Nilai keberlanjutan dimensi keberlanjutan tidak berbeda jauh dari nilai keberlanjutan multidimensi. Hasil analisis leverage (Gambar 8) dapat dilihat bahwa atribut sensitif yang paling mempengaruhi keberlanjutan pada dimensi teknologi adalah (1) mekanisme pengelolaan tanah; (2) jarak tanam; (3) penggunaan pupuk sesuai rekomendasi. Maka untuk meningkatkan keberlanjutan dimensi teknologi atribut-atribut tersebut perlu diperhatikan.

Dimensi teknologi pada penelitian ini terfokus pada agribisnis hulu perkebunan kelapa sawit yakni perkebunan rakyat, maka sentuhan teknologi pada perkebunan rakyat tidak banyak berubah ataupun berevolusi. Namun berdasarkan analisis leverage mekanisme pengelolaan tanah termasuk dalam atribut yang sensitif mempengaruhi keberlanjutan dimensi teknologi. Pada daerah 

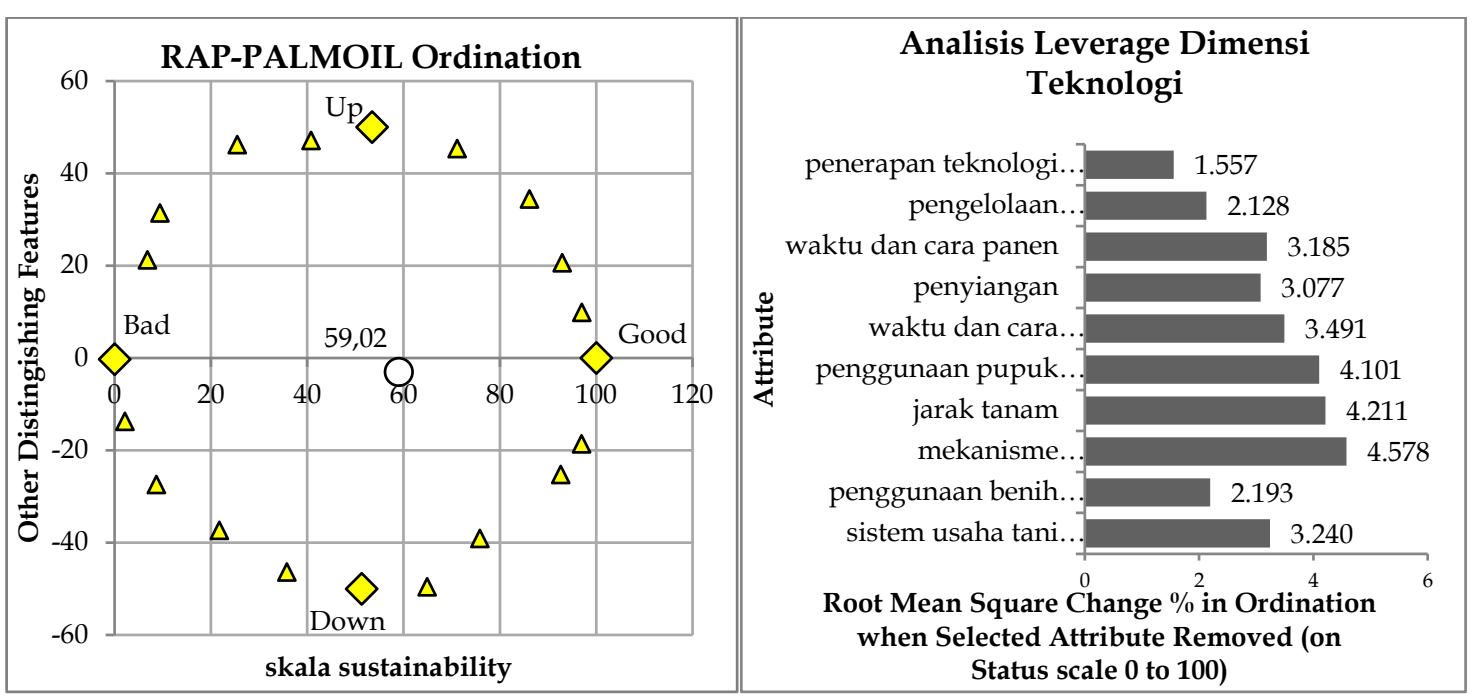

Gambar 8. Analisis Indeks Keberlanjutan Perkebunan Kelapa Sawit Rakyat Provinsi Jambi dan Faktor yang Paling Sensitif Mempengaruhi Keberlanjutan Dimensi Teknologi

penelitian mekanisme pengelolaan tanah baik pembukaan dan persiapan lahan hingga peremajaan masih menggunakan cara tradisional, petani belum mampu mengakses teknologi untuk pengelolaan tanah akibat kurang persiapan modal yang tidak sedikit.

Atribut lainnya adalah penggunaan bibit unggul dan jarak tanam. Pada penelitian ini masih banyak petani yang belum menggunakan bibit unggul bersertifikat terutama untuk tanaman lama. Petani masih merasa terbebani dengan harga bibit unggul bersertifikat dan memilih menggunakan bibit yang disemai sendiri. Pada atribut jarak tanam, masih banyak petani yang belum mengetahui kesesuaian jarak tanam berdasarkan jenis lahan sehingga sering menganggu tumbuh kembang tanaman yang mempengaruhi produksinya.

\section{IMPLIKASI KEBIJAKAN}

Pengembangan perkebunan kelapa sawit di Provinsi Jambi secara ekonomi mampu menopang kehidupan masyarakat terbukti dengan perkebunan kelapa sawit sebagai mata pencaharian utama. Berbagai dampak ekonomi yang ditimbulkan perkebunan kelapa sawit juga masih membutuhkan evaluasi berdasarkan atribut yang masih belum sesuai dengan prinsip pembangunan berkelanjutan.
Perkebunan kelapa sawit rakyat yang memiliki keterbatasan manajerial membutuhkan kelembagaan sebagai wadah yang mampu menyalurkan kebutuhan perkebunan kelapa sawit. Untuk itu, petani diharapkan mampu mengikuti dan menerapkan aspek kelembagaan yang tepat. Kelembagaan yang berkembang pada perkebunan kelapa sawit diharapkan mampu memetakan perkebunan kelapa sawit secara administratif.

Sertifikasi kelapa sawit menjadi tolak ukur keberlanjutan perkebunan kelapa sawit untuk memasuki perdagangan internasional. Perkebunan kelapa sawit rakyat sebagai bagian rantai pasok komoditi kelapa sawit diharapkan mampu mempersiapkan proses sertifikasi keberlanjutan. Persiapan keberlanjutan perkebunan kelapa sawit sebaiknya disiapkan sedini mungkin sehingga praktikpraktik keberlanjutan mampu diterapkan pada perkebunan kelapa sawit rakyat di Provinsi Jambi.

\section{KESIMPULAN DAN SARAN}

\section{KESIMPULAN}

1) Nilai indeks keberlanjutan perkebunan kelapa sawit rakyat Provinsi Jambi secara multidimensi adalah 57,79. Status keberlanjutan perkebunan kelapa sawit Provinsi Jambi adalah "cukup berkelanjutan". 
2) Nilai indeks keberlanjutan masing-masing dimensi berkisar antara 46,60 - 66,83 termasuk dalam kategori kurang-cukup berkelanjutan. Dimensi kelembagaan memiliki nilai keberlanjutan paling rendah pada kategori kurang berkelanjutan. Dimensi dengan nilai keberlanjutan tertinggi adalah dimensi sosial. Atribut-atribut sensitif mempengaruhi keberlanjutan terdapat 3 pada masing-masing dimensi yang mempengaruhi keberlanjutan perkebunan kelapa sawit rakyat Provinsi Jambi.

\section{SARAN}

1) Perlu dilakukan upaya peningkatan keberlanjutan perkebunan kelapa sawit rakyat dengan melihat atribut sensitif pada penelitian ini sebagai faktor penggerak keberlanjutan perkebunan kelapa sawit Provinsi Jambi. Infrastruktur, sarana pendidikan dan kesehatan merupakan hal yang perlu mendapat perhatian khusus dari pemerintah untuk segera di evaluasi pada daerah pedesaan yang dihuni oleh petani perkebunan kelapa sawit.

2) Pemerintah dan pemangku kebijakan sebaik-nya meningkatkan peran kelembagaan dan pengorganisasian pada usaha perkebunan kelapa sawit rakyat untuk memudahkan petani mengakses teknologi, bantuan sarana perkebunan, dan pelayanan penyuluhan pertanian.

\section{DAFTAR PUSTAKA}

Anantayu S. 2009. Partisipasi Petani Dalam Meningkatkan Kapasitas Kelembagaan Kelompok Petani. [disertasi]. Bogor: Sekolah Pascasarjana IPB. Bogor

Andriani. Evi. 2017. Analisis Sumber Pendapatan Petani Kelapa Sawit. JurnalAgrisep. 16(2): 2579-9959

[BPS]. Badan Pusat Statistik 2018 Statistik Perkebunan Kelapa Sawit. Jakarta. Badan Pusat Statistik
Baumgärtner, Martin Quaas. 2010. What is sustainability ecopapers; 69(3) 224-450

[COSCA]. Committee on sustainability assessment. 2013. The cosa measuring sustainability report; coffee and cocoa in 12 countries. Committee on Sustainability Assessment. Philadelpia.

[Ditjenbun]. Direktorat Jendral Perkebunan. 2014. Statistik perkebunan kelapa sawit indonesia. Sekretariat Direktorat Jendral Perkebunan.

http/ditjenbun.pertanian.go.id

Dalal-Calyton, B. S Bass. 2002. Sustainable Development Strategies, Aresoure Book. Organization For Economic CoOperation And Development Programme. Earthsan Publications Ltd, London.

Daulay AR et al. 2016. Analisis Faktor Penyebab Alih Fungsi Lahan Sawah Menjadi Sawit Di Kabupaten Tanjung Jabung Timur. Analisis Kebijakan Pertanian 14(1):1-15

Deng H. 2015. Multicriteria Analysis for Benchmarking Sustainability Development Banchmarking. International Journal 22(5):791-807.

Fauzi, A dan S. Anna. 2005. Pemodelan Sumberdaya Perikanan Kelautan Untuk Analisis Kebijakan. Penerbit Gramedia Pustaka. Jakarta

Hidayatno. M, Supiandi S. S Yahya. L I Amien. 2009. Analisis Keberlanjutan Perkebunan Kakao Rakyat Di Kawasan Perbatasan Pulau Sebatik Kabupaten Nunukan Provinsi Kalimantan Timur. Jurnal Agro Ekonomi. 27(2): 213-229

Kavanagh P Dan Pitcher TJ. 2004. Implementing Microsoft Excel Software For RAPFISH: A Technique For The Rapid Appraisal Of Fisheries Status. Fisheries Centre Research Reports.12(2): 3-75.

Kavanagh, P. 2001. Rapid Apraisal Off Fisheries (Rapfish) Projet. Rapfish Softwere De Eruption (For Mirosoft 
Excel). University Of British Columbia, Fisheries Enter, Vanonver.

Kementerian Pertanian. 2017. Outlook Kelapa Sawit. Jakarta

Munashinge, M. 1993. Envirinmental Economic And Sustainable Development. The International Bank For Reonstrution And Development/The World Bank. Washington, D.. 20433, U.S.A

Ngadi, Mita Noveria. 2015. Keberlanjutan Perkebunan Kelapa Sawit Di Indonesia Dan Prospek Pengembangan Di Kawasan Perbatasan. Masyarakat Indonesia 43(1)

Nurmalina, Rita. 2008. Analisis Indeks Dan Status Keberlanjutan Sistem Ketersediaan Beras di Beberapa Wilayah Indoneia. Jurnal Agro Ekonomi 26(1): 47-79

Nurmalina, Rita. 2008. Keberlanjutan Sistem Ketersediaan Beras Nasional: Pendekatan Teknik Ordinasi Rap-Rice Dengan Metoda Multidimensional Scaling (MDS). Jurnal Agribisnis dan Ekonomi Pertanian 2(2):1978-479

Ordóñez C, P N Duinker. 2010. Interpreting Sustainability for Urban Forests. Jurnal Canada 2:124-127. http://www.mdpi.com/20711050/2/6/1510

Pitcher, T.J., And P. David. 2001. RAPFISH: A Rapid Appraisal Technique To Evaluate The Sustainability Status Of Fisheries Research 49:255

Supriadi, Wiwin. 2013. Perekebunan Kelapa Sawit Dan Kesejahteraan Masyarakat di Kabupaten Sambas. Jurnal Ekonomi Daerah. 1(1):1978-7170

UN (United Nation), 2015, Transforming Our World: The 2030 Agenda for Sustainable Development. A/Res/70/1. United Nation.

www.Sustainabledevelopment.un.or

Utami. Rany, Eka Intan KS, Meti Ekayani. 2017. Dampak Ekonomi Dan Lingkungan Ekspansi Perkebunan Kelapa Sawit
(Studi Kasus: Desa Penyabungan, Kecamatan Merlung, Kabupaten Tanjung Jabung Barat, Jambi). Jurnal Ilmu Pertanian Indonesia (JIPI). 22(2): 2443-346 